\title{
Gga-miR-130b-3p inhibits MSB1 cell proliferation, migration, invasion, and its downregulation in MD tumor is attributed to hypermethylation
}

\author{
Chunfang Zhao ${ }^{1}$, Xin Li ${ }^{2}$, Bo Han ${ }^{1}$, Lujiang Qu ${ }^{1}$, Changjun Liu ${ }^{3}$, Jiuzhou Song ${ }^{4}$, Ling \\ Lian $^{1}$ and Ning Yang ${ }^{1}$ \\ ${ }^{1}$ Department of Animal Genetics and Breeding, College of Animal Science and Technology, China Agricultural University, \\ Beijing 100193, China \\ ${ }^{2}$ College of Animal Science and Veterinary Medicine, Tianjin Agricultural University, Tianjin 300384, China \\ ${ }^{3}$ Division of Avian Infectious Diseases, Harbin Veterinary Research Institute of Chinese Academy of Agricultural Sciences, \\ Harbin 150001, China \\ ${ }^{4}$ Department of Animal \& Avian Sciences, University of Maryland, College Park, Maryland 20742, United States \\ Correspondence to: Ning Yang, email: nyang@cau.edu.cn \\ Ling Lian, email: lianlinglara@126.com \\ Keywords: gga-miR-130b-3p; methylation; proliferation; migration; invasion \\ Received: November 16, $2017 \quad$ Accepted: February 27, $2018 \quad$ Published: May 11, 2018 \\ Copyright: Zhao et al. This is an open-access article distributed under the terms of the Creative Commons Attribution License 3.0 \\ (CC BY 3.0), which permits unrestricted use, distribution, and reproduction in any medium, provided the original author and source \\ are credited.
}

\section{ABSTRACT}

Marek's disease is an oncogenic and lymphoproliferative disease of chickens caused by Marek's disease virus. Hypermethylation or hypomethylation of CpG islands in gene promoter region are involved in the initiation and progression of carcinogenesis. In this study, we analyzed differential methylation levels of upstream region of gga-miR-130b-3p gene between Marek's disease virus-infected tumorous and non-infected spleens. Around the upstream $1 \mathrm{~kb}$ of gga-miR-130b-3p gene, two amplicons were designed that covered $616 \mathrm{bp}$. There were forty-eight CpG sites in this region. CpG sites in this region presented higher methylation level in tumorous spleens compared with that in non-infected ones. There were eight CpG sites significantly hypermethylated in tumorous spleens. The expression level of three DNA methyltransferases including DNMT1, DNMT3a and DNMT3b increased and the expression level of Tet ten-eleven translocation protein 2 remarkably decreased in tumorous spleens. Hypermethylation in the upstream region of gga-miR-130b-3p gene might be a direct reason for its downregulation in MD tumorous tissues. Moreover, cell proliferation of Marek's disease lymphoblastoid cell line MDCC-MSB1 was remarkably inhibited at 24, 36, 48, 60 and $72 \mathrm{~h}$ post-gga-miR-130b-3p-agomir transfection. The transwell migration assay indicated cell number of migration was significantly lower in miRNA agomir transfection group. Matrix metalloproteinases MMP2 and MMP9 are involved in tumor invasion, and their protein levels were significantly downregulated at $72 \mathrm{~h}$ post-miRNA-agomir transfection. Collectively, these results indicated that hypermethylation in upstream region of gga-miR-130b-3p gene contributed to its downregulation in tumorous tissues. Gga-miR-130b-3p plays an inhibitory role in lymphomatous cell transformation. 


\section{INTRODUCTION}

Marek's disease (MD) in chickens is a critical disease that threatens the development of poultry, which is caused by oncogenic herpes virus Marek's disease virus (MDV). This disease results in various clinical syndromes and is mainly characterized by immunosuppression, neuritis, and rapid-onset neoplastic T-cell lymphomas formation in multiple visceral organs [1-5]. Natural infection with MDV in vivo was typically divided into four phases, including the cytolytic infection stage (3 to 6 days post-infection [d.p.i.]), the latent infection stage (7 to 10 d.p.i.), the further cytolytic infection stage (10 to 14 d.p.i.) and the tumor transformation stage (after 21 d.p.i.) $[1,2]$.

MicroRNA (miRNA) is a class of small non-coding single-stranded RNA (approximately 22 nucleotides in length), which exerts post-transcriptional regulation of target gene expression by interacting with the 3 '-untranslated region of mRNA and suppressing mRNA translation, or a combination of both mechanisms [6-8]. Interaction between miRNA and target genes of miRNA at the post-transcriptional level provides fine-tuned dynamic regulation of cell signalling pathways [9]. miRNA is involved in various biological processes, including differentiation, development and tumorigenesis [10]. DNA methylation is a type of epigenetic modification that entails the covalent addition of a methyl group to the cytosine residue within the $\mathrm{CpG}$ context through the catalysis of DNA methyltransferases, which affects gene expression without genetic alterations [11]. Both miRNA and DNA methylation are crucial regulators of gene expression. The miRNA expression dysregulation in some cancers is an outcome of aberrant methylation states in the promotor regions of the miRNAs [11-14]. In fact, miRNAs act as both the effectors and targets in the DNA methyltransferases (DNMTs). MiRNAs can target $D N M T$ mRNA and inhibit their expression, which results in variations on genome-wide methylation patterns [11, $15,16]$.

Nowadays, there are numerous reports about the methylation in the promoter of miRNA in malignant tumors in mammals. Although both host and viral miRNAs are specifically implicated in MD tumorigenesis, similar study is limited and most studies were focused on global host and viral gene methylation [17-20]. The study of DNA methylation in MD has been carried out for a long time. Gathered data shows that DNA methylation have an impact on maintaining viral latency of MDV in the propagation process in vivo and in MDV-transformed lymphoblastoid cell lines in vitro [21, 22]. Tian et al. (2013) reported that DNA methylation levels in vitro are associated with MDV replication, and MDV propagation in the infected DF-1 cells is restricted by methylation inhibitor 5-azacytidine [23]. CD4 gene expression level was directly related to $\mathrm{T}$ cell development and its methylation level in the promoter was downregulated in
MD susceptible chickens [24]. MDV infection induced dynamic promotor methylation alterations and methylation variations were observed in the MD progression. By bisulfite pyrosequencing method, a few candidate genes were found to be involved in cell adhesion, immune system process, and responding to stimulus and higher methylated in the MD-susceptible 7 , line than in the MD-resistant $6_{3}$ line [25]. Hodgkin's disease antigen CD30 is over-expressed in chickens with MD and its overexpression results from hypomethylation in the promotor [26, 27].

MiR-130b functions as an oncogenic or tumor suppressor miRNA and shows dysregulation in various cancers including gastric, endometrial, and lung cancer [28-30]. Our previous study found gga-miR-130b-3p was abnormally expressed in MD tumorous tissues. To elucidate the reason for its differential expression and its function in MD tumorigenesis, we analyzed the methylation pattern of gga-miR-130b-3p gene and detected the effect of gga-miR-130b-3p on main features of MD lymphoblastoid cell line MDCC-MSB1.

\section{RESULTS}

\section{The upstream region of gga-miR-130b-3p gene was hypermethylated in MDV-infected tumorous spleens}

Our previous study investigated miRNA expression profiling between MD lymphoma and non-infected samples of chickens using Solexa deep sequencing, which showed that gga-miR-130b-3p expression was downregulated in MD lymphoma samples compared with that in non-infected ones. Its expression level was further determined between tumorous tissues and non-infected ones using qRT-PCR. The expression level of gga-miR-130b-3p was significantly downregulated in tumorous spleens and livers compared with that in non-infected samples, respectively (Figure 1). The methylation pattern for the upstream $1 \mathrm{~kb}$ region of ggamiR-130b-3p gene was analyzed. Two amplicons covering $616 \mathrm{bp}$ around this region were designed. There were fortyeight $\mathrm{CpG}$ sites in the upstream region of gga-miR-130b-3p gene. The methylation difference of each $\mathrm{CpG}$ site between tumorous and non-infected spleens was further compared. Though the methylation levels varied at different $\mathrm{CpG}$ sites, overall methylation level in tumorous spleens was higher than that in non-infected ones (Figure 2A). It was not methylated at $\mathrm{CpG}$ site 1 at both tumorous and non-infected spleens. The rate of methylation was significantly higher at CpG site 4, 19, 28, 32, 33, 38, 42 and 43 in tumorous spleens compared with that in non-infected ones. $\mathrm{CpG}$ site 39 showed the highest methylation level $(92.5 \%)$, whereas CpG site 2 had the lowest methylation level (40\%) (Figure 2B). We identified the transcription factor binding sites using MatInspector (Supplementary Table 1) [31]. Among them, some transcription factor binding sites existed in immune 


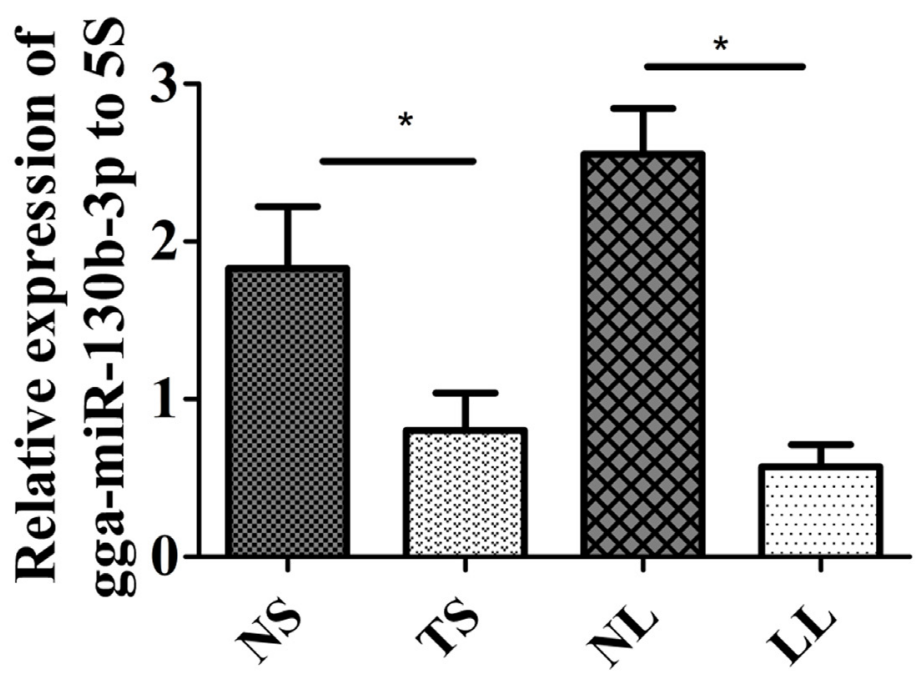

Figure 1: Expression level of gga-miR-130b-3p in MDV-infected tumorous and non-infected tissues. Expression level of gga-miR-130b-3p in non-infected spleen (NS), tumorous spleen (TS), non-infected liver (NL) and MD lymphoma from liver (LL) $(\mathrm{n}=8)$. The data are expressed as the mean \pm S.E. ${ }^{*} P<0.05$.
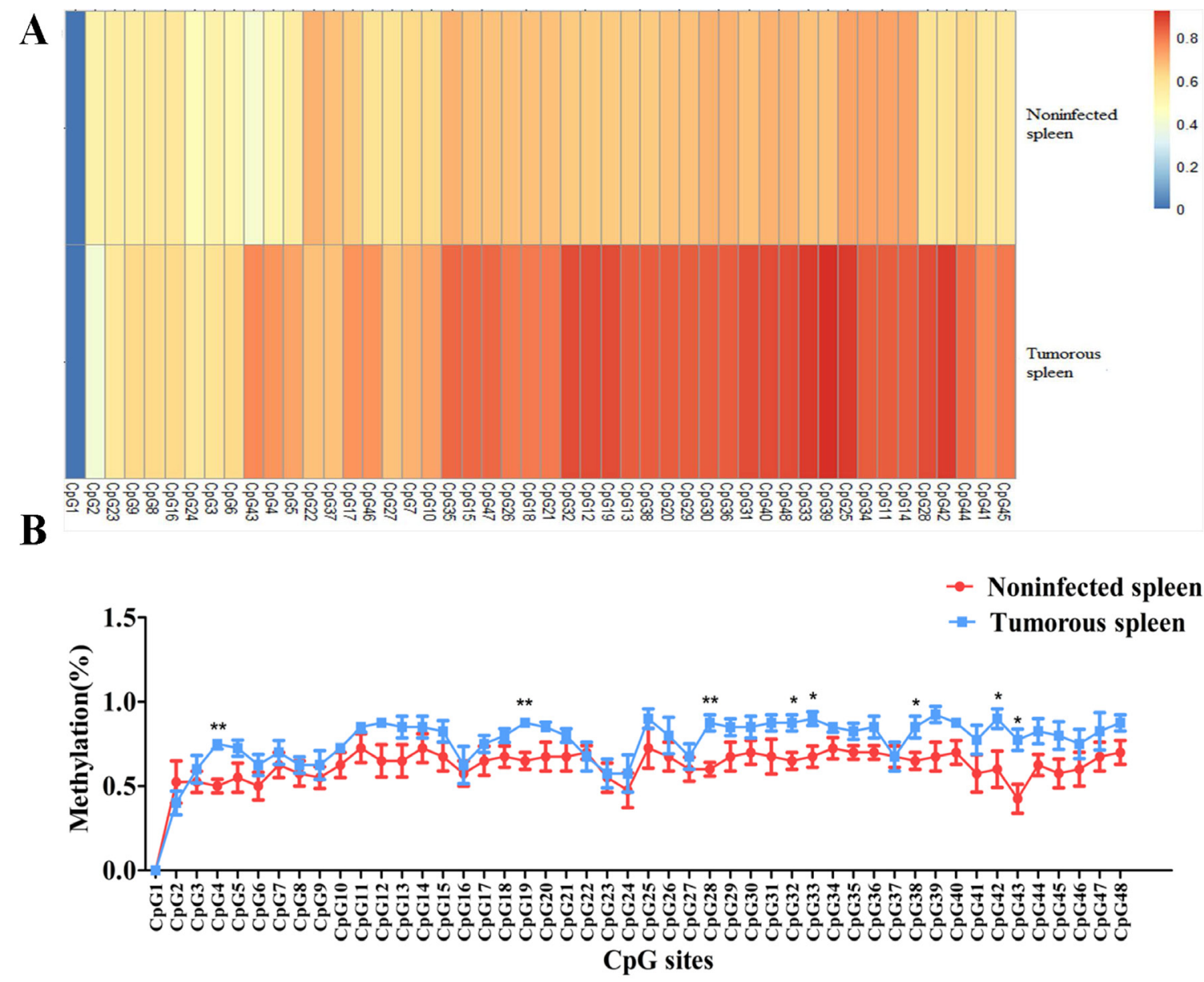

Figure 2: Methylation level of each CpG site in the upstream region of gga-miR-130b-3p gene between MDV-infected tumorous and non-infected spleens. (A) Heat map depicting methylation pattern of forty-eight $\mathrm{CpG}$ sites in the upstream region of gga-miR130b-3p gene between tumorous and non-infected spleens. (B) Line chart depicting methylation pattern of forty-eight $\mathrm{CpG}$ sites in the upstream region of gga-miR-130b-3p gene between tumorous and non-infected spleens. The data are expressed as the mean \pm S.E. ${ }^{*} P<0.05$. ${ }^{* *} P<0.01$. 
system and were involved in immune response, cell cycle regulation and tumorigenesis. The transcriptional factor stimulating protein 1 (SP1) binding site was predicted in the amplicon. There were four $\mathrm{CpG}$ sites in the SP1 binding site. The $S P 1$ binding site was located at the $\mathrm{CpG}$ site 24, $25,26,27$ in the upstream region of gga-miR-130b-3p gene and their methylation rate was $0.575,0.900,0.800,0.675$, respectively in tumorous spleens.

\section{DNMTs expression level was upregulated and TETs expression level was downregulated in MDV-infected tumorous spleens}

To reinforce the results above, the expression level of DNMTs and enzymes involved in demethylation was further analyzed. DNMTs expression levels including DNMT1, DNMT3a and DNMT3b were upregulated in MDV-infected tumorous spleens compared with that in non-infected ones (Figure 3A-3C). The enzymes Tet ten-eleven translocation (TET) proteins involved in demethylation include TET1, TET2 and TET3, and TET2 expression was significantly downregulated in tumorous spleens while TET1 and TET3 expression had no significant differences between tumorous and non-infected spleens (Figure 3D-3F).

\section{Gga-miR-130b-3p inhibited MSB1 cell proliferation, migration and invasion}

The MSB1 cells were transfected with the gga-miR$130 \mathrm{~b}-3 \mathrm{p}$ agomir to stimulate miRNA overexpression. The efficiency of transfection reached up to $70 \%$ (Figure $4 \mathrm{~A}$ ). Cell proliferation was lower in cultures at 24, 36, 48, 60 and $72 \mathrm{~h}$ post-agomir transfection than that in the $\mathrm{NC}$ transfection group (Figure 4B). The migration cell number significantly decreased when MSB1 cells were transfected with agomir (Figure 4C). The expression levels of two genes, $M M P 2$ and $M M P 9$, that are closely correlated to cell invasion were examined by qRT-PCR and ELISA. mRNA expression of $M M P 2$ had no significant differences post-agomir transfection (Figure 5A). mRNA expression of $M M P 9$ was significantly downregulated at $24 \mathrm{~h}$ and had no significant differences at 48 and $72 \mathrm{~h}$ post-agomir transfection (Figure 5B). The protein levels of both MMP2 and MMP9 significantly decreased post-agomir transfection at $72 \mathrm{~h}$ (Figure 5C, 5D).

\section{DISCUSSION}

Host and viral miRNAs as well as DNA methylation involved in Marek's disease tumorigenesis have been broadly reported. The study about DNA methylation was mostly focused on methylation status of viral and host coding genes. Latent MDV1 DNA is considerably methylated in MDV-transformed cell lines, which contributes to the repression of viral gene transcription $[22,32]$. However, MDV lytic genes like pp34 and pp28 is mostly non-methylated in MSB1 cells [33]. Yu et al. (2008) firstly analyzed the DNA methylation profiles of DNMTs in chickens with different MD resistance and provided tissue-specific methylation patterns of DNMT3a and agespecific methylation of DNMT1 [34]. Tian et al. (2013)
A
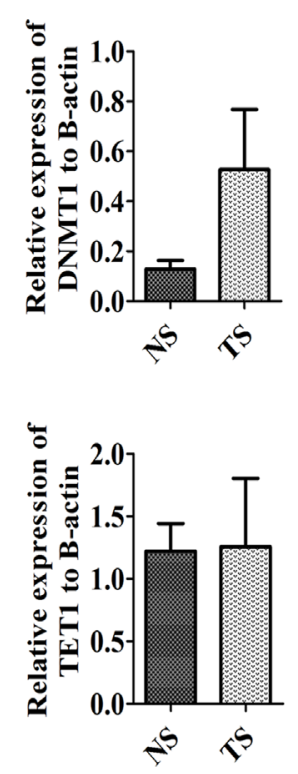

B

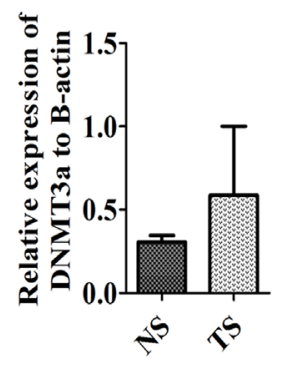

E

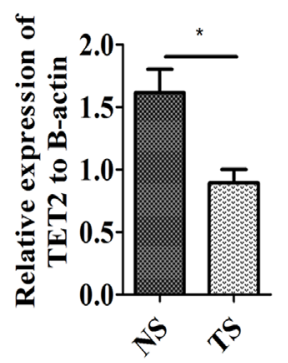

C

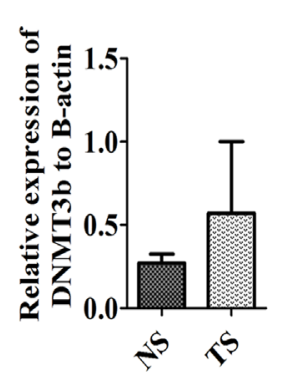

F

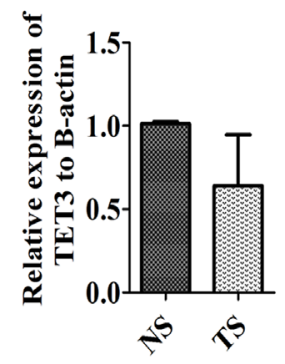

Figure 3: Expression level of DNA methyltransferases and Tet ten-eleven translocation proteins. (A, B, C) Expression level of DNMT1 (A), DNMT3a (B) and DNMT3b (C) in non-infected spleens (NS) and tumorous spleens (TS). (D, E, F) Expression level of TET1 (D), TET2 (E) and TET3 (F) in non- infected spleens (NS) and tumorous spleens (TS). The data are expressed as the mean \pm S.E. ${ }^{*} P<0.05$. 
mapped the chicken genome-wide DNA methylation profiles by methylation mapping analysis by paired-end sequencing and provides a more comprehensive picture of the chicken methylome [23]. Li et al. (2015) established a single-base resolution DNA methylation profile of chicken lung using whole-genome bisulfite sequencing and displayed differential DNA methylation patterns in chickens that differed in disease resistance [35]. They also found that the methylation level of miRNA promoters is high [35]. However, functional study on methylation of miRNA promoters in MD is limited.
Aberrant DNA methylation is a well-known feature of cancer cells. miRNAs have been shown to function as targets in gene hypermethylation in malignant cells. Increased methylation level of tumor suppressor miRNAs in turn results in overexpression of the oncogenic targets [36-38]. Epigenetic silencing of the tumor suppressor miR-124a by aberrant DNA hypermehtylation in colorectal cancer cell line HCT-116 resulted in its target gene cyclin D kinase- 6 overexpression and tumor suppressor gene retinoblastoma phosphorylation, both of which affects cell cycle progression [39]. And interestingly,

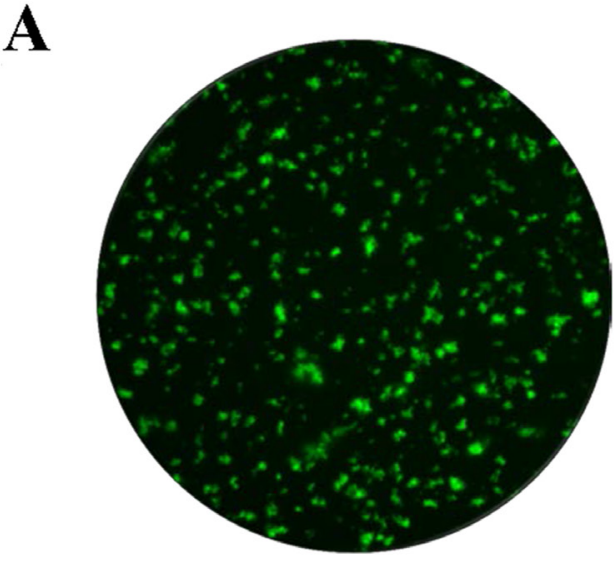

Dark field

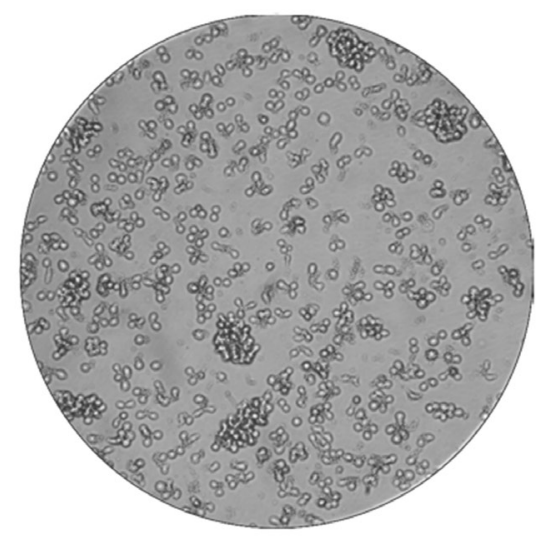

Bright field
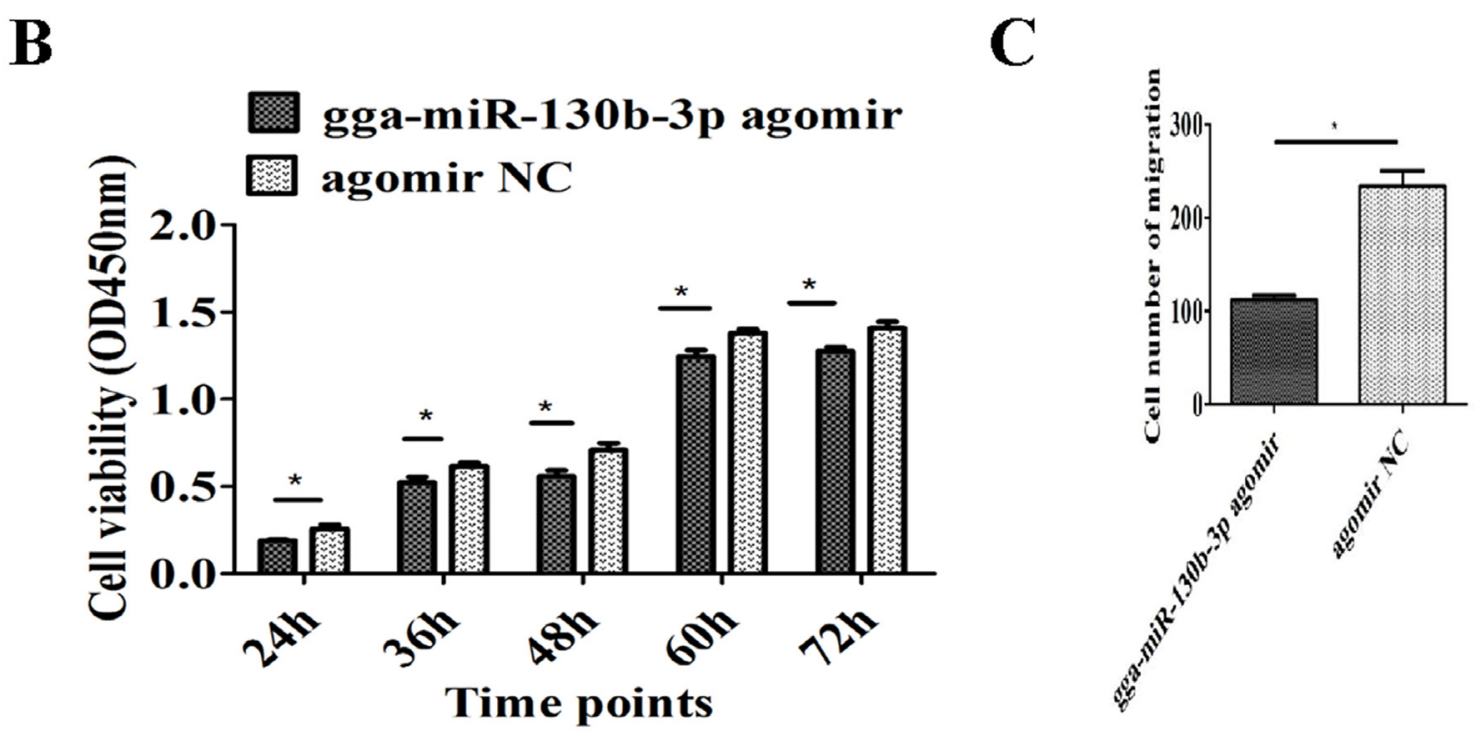

Figure 4: Effect of gga-miR-130b-3p on cell proliferation and migration. (A) Depiction of the miRNA agomir or agomir NC transfection efficiency. To show transfection efficiency of the agomir or agomir NC, a transfection reagent was used to transfect MSB1 cells with FAM-labelled agomir NC. A fluorescence microscope was used to observe the cells, which were illuminated under a bright or dark field with magnification at 100×. (B) Effect of gga-miR-130b-3p on MSB1 cell proliferation. Cell proliferation was detected by a CCK-8 assay at 24, 36, 48, 60 and $72 \mathrm{~h}$ after transfection with the gga-miR-130b-3p agomir or NC (n=5). (C) Effect of gga-miR-130b-3p on MSB1 cell migration. Transwell migration assay performed after transduction of the gga-miR-130b-3p agomir or NC $(n=2)$. The data are expressed as the mean \pm S.E. ${ }^{*} P<0.05$. 
miR-29 family reverted global gene methylation by targeting DNMT3a and DNMT3b directly in non-smallcell lung cancer (NSCLC) and acute myeloid leukemia cells $[15,16]$. The promoter $\mathrm{CpG}$ islands of miR-130b was not methylated in NSCLC [40]. However, it had an increased methylation frequency in breast cancer [41]. The promoter of miR-130b 301b cluster was significantly hepermethylated in prostate cancer tissues compared with morphologically normal ones, which impaired cellular senescence and fuel malignant transformation [42]. MiR-130b hypermethylation is observed in ovarian cancer tissues and demethylation leads to reactivation of miR-130b expression in drug resistant ovarian cancer cell lines [43]. We verified that gga-miR-130b$3 p$ was significantly downregulated in MDV-infected tumorous tissues. The upstream region of gga-miR- 130b-3p gene was hypermethylated in tumorous spleens. DNMTs expression level increased and the catalysis of $D N M T s$ contributes to its hypermethylation in tumorous spleens. TETS may be involved in the demethylation of 5-methylcytosine through 5-hydroxymethylcytosine as an intermediate in the chicken [44-46]. The expression of TET2 was downregulated in tumorous spleens, which may contribute to the lower demethylation in the upstream region of gga-miR-130b-3p gene. Transcription factor binding sites that bind with the upstream region of gga-miR-130b-3p gene were predicted through online software. Some transcription factor binding sites were correlated with immune response, cell cycle regulation and tumorigenesis. Transcription factor SP1 binding site was found in the upstream region of this miRNA. SP1 is a zinc finger transcription factor that binds to GC-rich

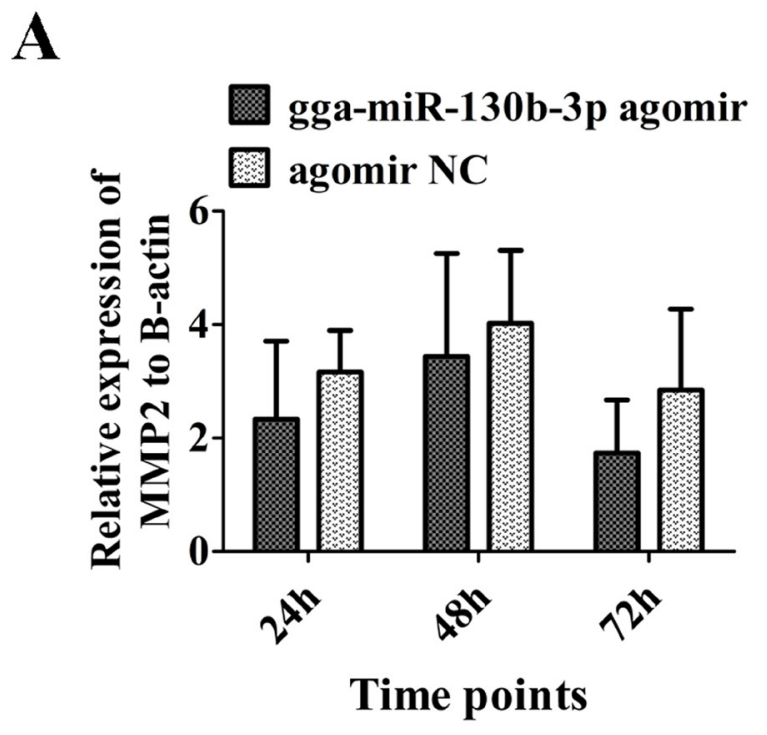

B

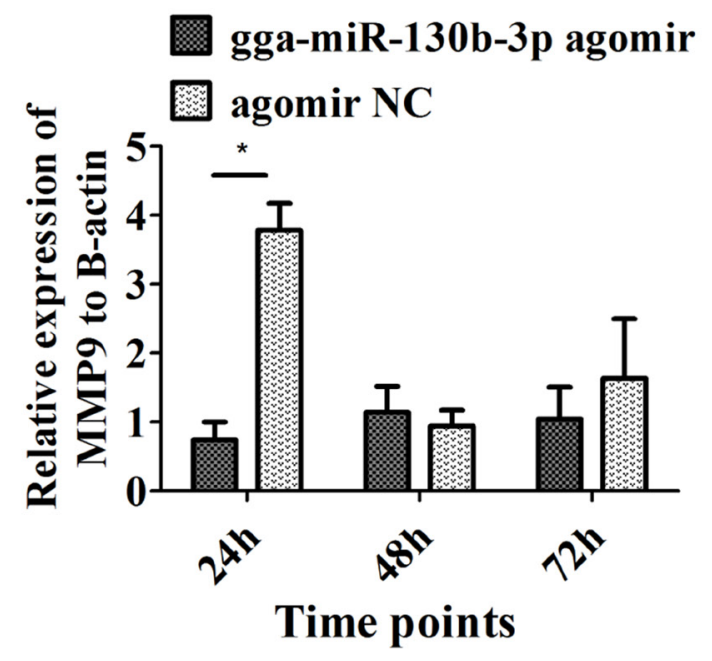

C

D
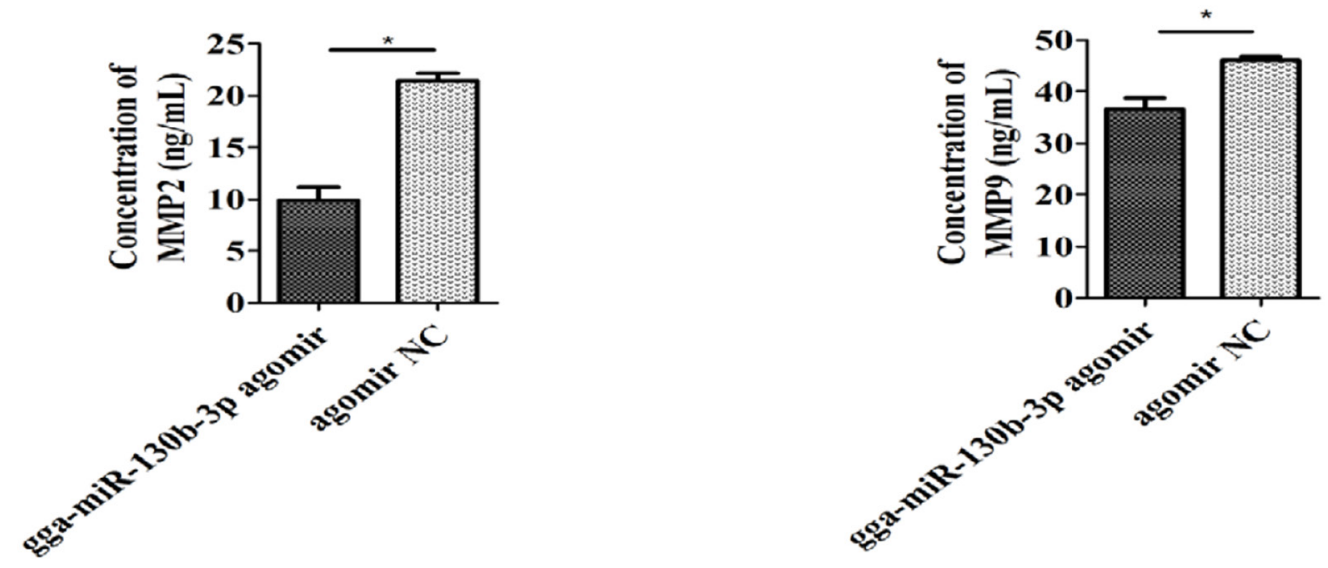

Figure 5: Effect of gga-miR-130b-3p on cell invasion. mRNA level of MMP2 (A) and MMP9 (B) after transduction of the ggamiR-130b-3p agomir or NC $(n=3)$. The protein level of MMP2 (C) and MMP9 (D) after transduction of the gga-miR-130b-3p agomir or $\mathrm{NC}(\mathrm{n}=3)$. The data are expressed as the mean \pm S.E. ${ }^{*} P<0.05 .{ }^{* *} P<0.01$. 
Table 1: Primers for genes used in the RT-qPCR.

\begin{tabular}{lcc}
\hline Gene & Direction & Sequence \\
\hline$\beta$-actin & Forward & 5'-GAGAAATTGTGCGTGACATCA-3' \\
& Reverse & 5'-CCTGAACCTCTCATTGCCA-3' \\
MMP2 & Forward & 5'-TGAAACAGGAGATTTGGAT-3' \\
& Reverse & 5'-CATTTTGGCTTTCTTGGA-3' \\
MMP9 & Forward & 5'-ACCTGGACCGTGCCGTGAT-3' \\
& Reverse & 5'-TGCCTCGCCGCTGTAAAT-3' \\
\hline
\end{tabular}

motifs of many gene promoters [47]. It is involved in many cellular processes, including cell growth, apoptosis, response to DNA damage and immune response [48, 49]. Many reports indicate it is overexpressed in cancers and is associated with tumorigenesis [50-53]. SP1 plays a role in both gene transcriptional regulation and epigenetic regulation through modulating gene silencing by DNA methylation [54]. SP1 protects the 5' promoter regions of housekeeping and other genes from being silenced [55-57]. And it inhibits $S P 1$ binding when methylation spreads into $S P 1$ binding sites, which leads to silencing of transcription [58]. Changes in histone $\mathrm{H} 3$ modifications of tumor suppressor $R A S S F 1 A$ gene contribute to the eviction of $S P 1$ from the promoter region, and the loss of SP1 allows CpG methylation in the promoter [59]. The SP1 binding site was located at the CpG site 24, 25, 26, 27 in the upstream region of gga-miR-130b-3p gene and their methylation level in these four $\mathrm{CpG}$ sites were all higher in tumorous spleens compared with that in noninfected ones. Cyclin A-cyclin-dependent kinase $(C D K) 2$ complexes can phosphorylate $S P 1$, while cyclin A-CDK2mediated phosphorylation augments SP1 DNA binding properties [60, 61]. Phosphorylation of MDV oncogene $M e q$ by $C D K 2$ that colocalize with $M e q$ drastically reduces the DNA binding activity of $M e q$, and perhaps results in the translocation of $\mathrm{Meq}$ to cytoplasm. Enhanced transport of $\mathrm{Meq}$ is profitable to the maintenance of MDV latent state. $\mathrm{Meq}$ might directly or indirectly translocate $C D K 2$ to coiled bodies to promote cell cycle progression during the course of transformation [62]. We assumed that MDV infection might inhibit SP1 DNA binding properties owing to loss of $C D K 2$ phosphorylation. SP1 has the function of preventing the gene promoter from methylation and thus SP1 might be prevented from binding to the promoter of gga-miR-130b-3p, which results in the methylation of this miRNA. However, it remains to be validated through further study.

Aberrant methylation of the gene promoter regions in both suppressor and oncogenic miRNAs is involved in all key processes related to tumor development of neoplastic phenotype: uncontrolled cell proliferation, bypassed apoptotic program, and ability for invasion and metastasis spread $[9,63]$. We analyzed the effects of gga-
miR-130b-3p on tumorous cell features. Its downregulation in MDV-infected tissues implicates its involvement in MD tumorigenesis. Gga-miR-130b-3p expression level was slightly lower in MDV-infected CEF cells [64], which was similar with our data. Overexpression of gga-miR-130b-3p remarkably inhibited MSB1 cell proliferation at different time points. In $\mathrm{GH} 3$ rat pituitary tumor cells, miR-130b inhibited cell proliferation by arresting the cells in the G1 and G2 phase of the cell cycle through targeting cyclin A2 gene [65]. MiR-130b arrested cell cycle at $\mathrm{S}$ phase and induced apoptosis in human pancreatic cancer PANC-2 and ASPC-1 cell lines, which resulted in suppression in cell proliferation both in vitro and in vivo [66].

MiR-130b inhibited cell migration and invasion in epithelial ovarian cancer cells [67]. Overexpression of miR-130b remarkably inhibited the invasive ability of pancreatic cancer cells [66]. Moreover, a number of miRNA genes susceptible to methylation are closely correlated with cell migration, metastasis, and adhesion [9]. The overexpression of gga-miR-130b-3p prohibited the migration ability of MSB1 cells. Matrix metalloproteinases (MMPS) are known to be involved in tumor invasion and metastasis [68-70]. MMP2 and $M M P 9$ are two important matrix proteinases in the $M M P$ family that degrade type IV collagen, a major component of the basement membrane in cancers [71]. Gga-miR-130b-3p inhibited the expression level of $M M P 2$ and $M M P 9$, which indicates that this miRNA may be involved in MD tumor transformation through suppressing cell invasion.

The hypermethylation may contribute to the downregulation of gga-miR-130b-3p in MDV-infected tumorous tissues. Overexpression of gga-miR-130b$3 \mathrm{p}$ inhibited cell proliferation, migration and invasion, indicating that this miRNA may function as a tumor suppressor to be involved in MD tumor transformation.

\section{MATERIALS AND METHODS}

\section{Ethics statements}

All animal experiment procedures and sample collection strictly followed the protocols approved by the Animal Care and Use Committee of China Agricultural 
University (Approval ID: XXCB-20090209), and this study was carried out in strict accordance with the guidelines and regulations established by this committee and has been approved by review board of our university.

\section{Sample collection}

MDV-infected tumorous spleens and livers were obtained from a previously reported experiment [18]. All tissues were stored at $-80^{\circ} \mathrm{C}$ in RNA fixer. Total RNA was isolated from these tissues to detect differential expression of miRNAs.

\section{Bisulfite treatment}

Genomic DNA from the spleens was extracted by traditional phenol and chloroform methods. The quality of DNA was evaluated by $0.8 \%$ agarose gel electrophoresis using $100 \mathrm{ng}$ extracted DNA. The concentration was detected by NanoDrop (GE Healthcare, USA) spectrophotometer, and then a total of $1.5 \mu \mathrm{g}$ genomic DNA from each sample was treated with sodium bisulfite using an EZ DNA Methylation-Gold Kit (Zymo Research, Orange, CA) according to the manufacturer's protocol.

\section{Quantitative methylation analysis}

The upstream $1 \mathrm{~kb}$ region of gga-miR-130b-3p gene was determined using Ensembl Genome Browser (http://asia.ensembl.org) and $\mathrm{CpG}$ islands of this region were predicted using Methprimer (http://www.urogene. org/methprimer/). PCR primers were designed by using Methyl Primer Express Software of ABI company (Applied Biosystems, Foster City, CA). Two amplicons were designed to cover the upstream region of precursor gga-miR-130b-3p. Converted DNA was amplified with two sequential PCR using the following nested primers: PCR1:5'-GTGATTAGTTAAGGGATAAAGT-3' and 5'-AAACAACTCACCCAATTCTC-3', PCR2:5'-TGA TTAGTTAAGGGATAAAGTTAGGT-3' and 5'-CATC TTCCATTTTCACCCACT-3'. For each PCR, 25uL premix, $1 \mu \mathrm{M}$ of forward and reverse primers were used in a $50 \mu \mathrm{L}$ total reaction volume. Converted DNA (100 ng) was used as the template of the first PCR. The product $(5 \mu \mathrm{L})$ from $1^{\text {st }}$ PCR was used as the template for the second PCR. The first PCR amplification was performed as follows: $95^{\circ} \mathrm{C}$ for $3 \mathrm{~min}, 50$ cycles of $95^{\circ} \mathrm{C}$ for $5 \mathrm{~s}, 60^{\circ} \mathrm{C}$ for $20 \mathrm{~s}$, $72^{\circ} \mathrm{C}$ for $20 \mathrm{~s}$, and $72^{\circ} \mathrm{C}$ for $10 \mathrm{~min}$, finally incubation at $4^{\circ} \mathrm{C}$. The second PCR amplification was performed as follows: $95^{\circ} \mathrm{C}$ for $5 \mathrm{~min}, 25$ cycles of $95^{\circ} \mathrm{C}$ for $10 \mathrm{~s}, 60^{\circ} \mathrm{C}$ for $25 \mathrm{~s}, 72^{\circ} \mathrm{C}$ for $45 \mathrm{~s}$, and a final extension of $72^{\circ} \mathrm{C}$ for $10 \mathrm{~min}$. The $2^{\text {nd }} \mathrm{PCR}$ products were purified by gel extraction from a $1 \%$ agarose gel, sub-cloned into a pGEM T-Easy vector (Promega, Madison, WI, USA) and then transformed into Escherichia coli (strain DH5a) using standard procedures. Methylation state of each $\mathrm{CpG}$ site was analyzed by randomly sequencing 10 clones.

\section{Cell culture and miRNA transfection}

The MDV-transformed lymphoid cell line MDCCMSB1, which was kindly provided by Division of Avian Infectious Diseases, Harbin Veterinary Research Institute of Chinese Academy of Agricultural Sciences in May, 2017, was cultured in RPMI-1640 (Invitrogen, Carlsbad, CA) with 10\% fetal bovine serum (Invitrogen). The cell line was maintained in a sterile incubator at $37{ }^{\circ} \mathrm{C}, 95 \%$ humidity, and 5\% CO2. The cells were authenticated by testing ten chicken microsatellite sites (MCW0295, MCW0103, ADL0176, MCW0183, MCW0081, MCW0256, ADL0267, MCW0078, MCW0034, and ADL0210) when we first obtained the cells and started the experiment. FuGENE HD (Promega) was used to transfect cells according to manufacturer's instructions. The gga-miR-130b-3p agomir and corresponding NC were purchased from GenePharma Company (GenePharma Co. Ltd., Shanghai, China).

\section{Cell proliferation and migration assays}

Cell proliferation was detected using the Cell Counting Kit-8 (CCK-8) (Beyotime, Shanghai, China). The cells were seeded into 96 -well plates $\left(3 \times 10^{4}\right.$ cells/ well) and transfected with gga-miR-130b-3p agomir or agomir NC. Cell proliferation was detected at 24, 36, 48, 60 and $72 \mathrm{~h}$ post transfection. The absorbance at $450 \mathrm{~nm}$ was measured using a microplate spectrophotometer. All the experiments were performed independently in six replicates.

For migration assay, it was performed using the transwell. In total of $1.5 \times 10^{5}$ cells were seeded into 24 well plates and transfected with gga-miR-130b-3p agomir or agomir NC. After $48 \mathrm{~h}$ post transfection, cells were collected and washed with PBS. Firstly, $5 \times 10^{4}$ cells in serum-free medium were placed into the upper chamber of an insert (8-mm pore size; BD Bioscience, San Jose, CA). Medium containing $20 \%$ fetal bovine serum was added to the lower chamber. After 16-18 h of incubation, the cells remaining on the upper membrane were removed, and the cells that had migrated through the membrane were counted by a microscope. Each assay was performed in two replicates.

\section{RNA isolation and real-time PCR analysis}

Total RNA was isolated from frozen samples or MSB1 cells using TRIzol Reagent (Invitrogen) according to the manufacturer's protocol. Total RNA was reverse transcribed by cDNA synthesis kit (miRACLE, USA) for miRNA expression detection. The qRT-PCR for miRNA was conducted by qPCR miRNA kit (miRACLE) according to manufacturer's protocol. Specific forward primer for gga-miR-130b$3 p$ was 5'-AGTGCAATAATGAAAGGGCGTAA-3'. Specific forward primer for internal control $5 \mathrm{~S}$ was 
5'-ACCGGGTGCTGTAGGCTTAA-3'. Each individual sample for gga-miR-130b-3p detection was run in triplicate. The optimum thermal cycling parameters were $95^{\circ} \mathrm{C}$ for $10 \mathrm{~min}, 40$ cycles of $95^{\circ} \mathrm{C}$ for $10 \mathrm{~s}, 57^{\circ} \mathrm{C}$ for 20 $\mathrm{s}$, and $72^{\circ} \mathrm{C}$ for $1 \mathrm{~min}$.

Total RNA was reverse transcribed by EasyScript First-Strand cDNA Synthesis SuperMix (TransGen, Beijng, China) for specific gene detection. Real-time PCR reactions for specific genes were performed with the Power SYBR Green PCR Master Mix (Invitrogen) in the ABI 7500 System (Applied Biosystems) in triplicate. Primers for $M M P 2$ and $M M P 9$ genes used for the RT-qPCR were are shown in Table 1. Primers for DNMT1, DNMT3 $a$ and DNMT3b genes used for the RT-qPCR were reffered from Tian et al. (2013) [23]. Primers for TET1, TET2 and TET3 genes used for the RT-qPCR were reffered from Okuzaki et al. (2017) [46]. The relative genes expression level was calculated with reference to expression of $5 \mathrm{~S}$ and $\beta$-actin. The results are described as the fold change determined by $2^{-\Delta \Delta \mathrm{Ct}}$ method. The data are expressed as means \pm standard errors (SEs).

\section{Enzyme-linked immunosorbent assay (ELISA)}

The levels of the protein products of $M M P 2$ and $M M P 9$ genes were detected with ELISAs (BG, Shanghai, China). Cell supernatants were collected and centrifuged at $1,000 \times g$ for $15 \mathrm{~min}$ to remove debris. Cells were suspended in phosphate-buffered saline and subjected to ultrasonication. The ELISAs were conducted according to the manufacturer's protocol.

\section{Statistical analysis}

The data are expressed as means \pm SEs. All analyses were analyzed by a Student's $t$-test using the SAS system (SAS Institute Inc., Cary, NC). Values were considered to be significantly different when $P<0.05$.

\section{Abbreviations}

MD: Marek's disease

MDV: Marek's disease virus

miRNA: microRNA

d.p.i: days post infection

DNMT: DNA methyltransferase

CCK-8: Cell Counting Kit-8

SE: standard error

SP1: stimulating protein 1

NC: negative control

NSCLC : non-small-cell lung cancer

CDK: cyclin-dependent kinase

MMP: matrix metalloproteinase

TET: Tet ten-eleven translocation protein

ELISA : enzyme-linked immunosorbent assay

\section{Author contributions}

CZ, LL and NY designed the study. CZ and XL performed the experiments. CZ, NY and LL wrote the manuscript. CZ, LL, BH and XL analysed the data. LQ, $\mathrm{CL}, \mathrm{NY}$ and JS helped revise the manuscript. All authors discussed the data. All authors reviewed the manuscript.

\section{CONFLICTS OF INTEREST}

The authors declare no competing financial interests.

\section{FUNDING}

The work was supported in part by the National Natural Science Foundation of China (31320103905 and 31301957), the Program for Changjiang Scholars and Innovative Research in University of China (IRT_15R62), National High Technology Development Plan of China (2013AA102501, 2011AA100305), China Agriculture Research Systems (CARS-41), Farm Animals Germplasm Resource Platform, and Young Scientist Supporting Project.

\section{REFERENCES}

1. Calnek BW. Marek's disease-a model for herpesvirus oncology. Crit Rev Microbiol. 1986; 12:293-320.

2. Calnek BW. Pathogenesis of Marek's disease virus infection. Curr Top Microbiol Immunol. 2001; 255:25-55.

3. Biggs PM. The Leeuwenhoek Lecture, 1997. Marek's disease herpesvirus: Oncogenesis and prevention. Philos Trans R Soc Lond B Biol Sci. 1997; 352:1951-62. https:// doi.org/10.1098/rstb.1997.0181.

4. Jarosinski KW, Tischer BK, Trapp S, Osterrieder N. Marek's disease virus: Lytic replication, oncogenesis and control. Expert Rev Vaccines. 2006; 5:761-72. https://doi. org/10.1586/14760584.5.6.761.

5. Burnside J, Morgan RW. Genomics and Marek's disease virus. Cytogenet Genome Res. 2007; 117:376-87. https:// doi.org/10.1159/000103201.

6. Brennecke J, Stark A, Russell RB, Cohen SM. Principles of microRNA-target recognition. PLoS Biol. 2005; 3:e85. https://doi.org/10.1371/journal.pbio.0030085.

7. Guo H, Ingolia NT, Weissman JS, Bartel DP. Mammalian microRNAs predominantly act to decrease target mRNA levels. Nature. 2010; 466:835-40. https://doi.org/10.1038/ nature 09267.

8. Flynt AS, Lai EC. Biological principles of microRNAmediated regulation: shared themes amid diversity. Nat Rev Genet. 2008; 9:831-42. https://doi.org/10.1038/nrg2455.

9. Loginov VI, Rykov SV, Fridman MV, Braga EA. Methylation of miRNA genes and oncogenesis. Biochemistry (Mosc). 2015; 80:145-62. https://doi. org/10.1134/S0006297915020029. 
10. Bartel DP. MicroRNAs: genomics, biogenesis, mechanism, and function. Cell. 2004; 116:281-97.

11. Chhabra R. miRNA and methylation: A multifaceted liaison. ChemBioChem. 2015; 16:195-203. https://doi.org/10.1002/ cbic. 201402449.

12. Mudduluru G, Ceppi P, Kumarswamy R, Scagliotti GV, Papotti M, Allgayer H. Regulation of Axl receptor tyrosine kinase expression by miR-34a and miR-199a/b in solid cancer. Oncogene. 2011; 30:2888-99. https://doi. org/10.1038/onc.2011.13.

13. Tanaka N, Toyooka S, Soh J, Kubo T, Yamamoto H, Maki Y, Muraoka T, Shien K, Furukawa M, Ueno T, Asano H, Tsukuda K, Aoe K, et al. Frequent methylation and oncogenic role of microRNA-34b/c in small-cell lung cancer. Lung Cancer. 2012; 76:32-8. https://doi. org/10.1016/j.lungcan.2011.10.002.

14. Langevin SM, Stone RA, Bunker CH, Lyons-Weiler MA, LaFramboise WA, Kelly L, Seethala RR, Grandis JR, Sobol RW, Taioli E. MicroRNA-137 promoter methylation is associated with poorer overall survival in patients with squamous cell carcinoma of the head and neck. Cancer. 2011; 117:1454-62. https://doi.org/10.1002/cncr.25689.

15. Fabbri M, Garzon R, Cimmino A, Liu Z, Zanesi N, Callegari E, Liu S, Alder H, Costinean S, FernandezCymering C, Volinia S, Guler G, Morrison CD, et al. MicroRNA-29 family reverts aberrant methylation in lung cancer by targeting DNA methyltransferases 3A and 3B. Proc Natl Acad Sci U S A. 2007; 104:15805-10. https://doi. org/10.1073/pnas.0707628104.

16. Garzon R, Liu S, Fabbri M, Liu Z, Heaphy CE, Callegari E, Schwind S, Pang J, Yu J, Muthusamy N, Havelange V, Volinia S, Blum W, et al. MicroRNA-29b induces global DNA hypomethylation and tumor suppressor gene reexpression in acute myeloid leukemia by targeting directly DNMT3A and 3B and indirectly DNMT1. Blood. 2009; 113:6411-8. https://doi.org/10.1182/blood-2008-07-170589.

17. Tian F, Luo J, Zhang H, Chang S, Song J. MiRNA expression signatures induced by Marek's disease virus infection in chickens. Genomics. 2012; 99:152-9. https:// doi.org/10.1016/j.ygeno.2011.11.004.

18. Lian L, Qu L, Chen Y, Lamont SJ, Yang N. A systematic analysis of miRNA transcriptome in Marek's disease virus-induced lymphoma reveals novel and differentially expressed miRNAs. PLoS One. 2012; 7:e51003. https://doi. org/10.1371/journal.pone.0051003.

19. Luo J, Teng M, Fan J, Wang F, Zhou L, Deng R, Zhang G. Marek's disease virus-encoded microRNAs: Genomics, expression and function. Sci China Life Sci. 2010; 53:117480. https://doi.org/10.1007/s11427-010-4073-6.

20. Burnside J, Bernberg E, Anderson A, Lu C, Meyers BC, Green PJ, Jain N, Isaacs G, Morgan RW. Marek's disease virus encodes MicroRNAs that map to meq and the latencyassociated transcript. J Virol. 2006; 80:8778-86. https://doi. org/10.1128/jvi.00831-06.
21. Nair V. Latency and tumorigenesis in Marek's disease. Avian Dis. 2013; 57:360-5. https://doi.org/10.1637/10470-121712-Reg.1.

22. Hayashi M, Furuichi T, Ren S, Isogai E, Nonoyama M, Namioka S. Enhancement of mRNA synthesis from Marek's disease virus genome in the lymphoblastoid cell line, MDCC-MSB1, by 5-azacytidine. J Vet Med Sci. 1994; 56:287-91.

23. Tian F, Zhan F, VanderKraats ND, Hiken JF, Edwards JR, Zhang H, Zhao K, Song J. DNMT gene expression and methylome in Marek's disease resistant and susceptible chickens prior to and following infection by MDV. Epigenetics. 2013; 8:431-44. https://doi.org/10.4161/ epi.24361.

24. Luo J, Yu Y, Zhang H, Tian F, Chang S, Cheng HH, Song J. Down-regulation of promoter methylation level of CD4 gene after MDV infection in MD-susceptible chicken line. BMC Proc. 2011; 5:S7. https://doi. org/10.1186/1753-6561-5-S4-S7.

25. Luo J, Yu Y, Chang S, Tian F, Zhang H, Song J. DNA methylation fluctuation induced by virus infection differs between MD-resistant and -susceptible chickens. Front Genet. 2012; 3:20. https://doi.org/10.3389/ fgene.2012.00020.

26. Zhang $\mathrm{W}, \mathrm{Qu} \mathrm{L}, \mathrm{Xu}$ G, Lian L, Zheng J, Yang N. Hypomethylation upregulates the expression of CD30 in lymphoma induced by Marek's disease virus. Poult Sci. 2012; 91:1610-8. https://doi.org/10.3382/ps.2011-02086.

27. Li K, Lian L, Yang N, Qu L. Temporal expression and DNA hypomethylation profile of CD30 in Marek's disease virus-infected chicken spleens. Poult Sci. 2015; 94:1165-9. https://doi.org/10.3382/ps/pev100.

28. Sun B, Li L, Ma W, Wang S, Huang C. MiR-130b inhibits proliferation and induces apoptosis of gastric cancer cells via CYLD. Tumour Biol. 2016; 37:7981-7. https://doi. org/10.1007/s13277-015-4632-3.

29. Li BL, Lu C, Lu W, Yang TT, Qu J, Hong X, Wan XP. miR$130 \mathrm{~b}$ is an EMT-related microRNA that targets DICER1 for aggression in endometrial cancer. Med Oncol. 2013; 30:484. https://doi.org/10.1007/s12032-013-0484-0.

30. Tian J, Hu L, Li X, Geng J, Dai M, Bai X. MicroRNA$130 \mathrm{~b}$ promotes lung cancer progression via PPARgamma/ VEGF-A/BCL-2-mediated suppression of apoptosis. J Exp Clin Cancer Res. 2016; 35:105. https://doi.org/10.1186/ s13046-016-0382-3.

31. Quandt K, Frech K, Karas H, Wingender E, Werner T. MatInd and MatInspector: New fast and versatile tools for detection of consensus matches in nucleotide sequence data. Nucleic Acids Res. 1995; 23:4878-84.

32. Kanamori A, Ikuta K, Ueda S, Kato S, Hirai K. Methylation of Marek's disease virus DNA in chicken T-lymphoblastoid cell lines. J Gen Virol. 1987; 68: 1485-90. https://doi. org/10.1099/0022-1317-68-5-1485.

33. Parcells MS, Dienglewicz RL, Anderson AS, Morgan RW. Recombinant Marek's disease virus (MDV)-derived 
lymphoblastoid cell lines: Regulation of a marker gene within the context of the MDV genome. J Virol. 1999; 73:1362-73.

34. Yu Y, Zhang H, Tian F, Zhang W, Fang H, Song J. An integrated epigenetic and genetic analysis of DNA methyltransferase genes (DNMTs) in tumor resistant and susceptible chicken lines. PLoS One. 2008; 3:e2672. https:// doi.org/10.1371/journal.pone.0002672.

35. Li J, Li R, Wang Y, Hu X, Zhao Y, Li L, Feng C, Gu X, Liang F, Lamont SJ, Hu S, Zhou H, Li N. Genome-wide DNA methylome variation in two genetically distinct chicken lines using MethylC-seq. BMC Genomics. 2015; 16:851. https://doi.org/10.1186/s12864-015-2098-8.

36. Lopez-Serra P, Esteller M. DNA methylation-associated silencing of tumor-suppressor microRNAs in cancer. Oncogene. 2012; 31:1609-22. https://doi.org/10.1038/ onc.2011.354.

37. Di Leva G, Garofalo M, Croce CM. MicroRNAs in cancer. Annu Rev Pathol. 2014; 9:287-314. https://doi.org/10.1146/ annurev-pathol-012513-104715.

38. Saito Y, Liang G, Egger G, Friedman JM, Chuang JC, Coetzee GA, Jones PA. Specific activation of microRNA-127 with downregulation of the proto-oncogene BCL6 by chromatin-modifying drugs in human cancer cells. Cancer Cell. 2006; 9:435-43. https://doi.org/10.1016/j. ccr.2006.04.020.

39. Lujambio A, Ropero S, Ballestar E, Fraga MF, Cerrato C, Setien F, Casado S, Suarez-Gauthier A, Sanchez-Cespedes M, Git A, Spiteri I, Das PP, Caldas C, et al. Genetic unmasking of an epigenetically silenced microRNA in human cancer cells. Cancer Res. 2007; 67:1424-9. https:// doi.org/10.1158/0008-5472.can-06-4218.

40. Rykov SV, Khodyrev DS, Pronina IV, Kazubskaya TP, Loginov VI, Braga EA. Novel miRNA genes methylated in lung tumors. Genetika. 2013; 49:896-901.

41. Loginov VI, Burdennyy AM, Pronina IV, Khokonova VV, Kurevljov SV, Kazubskaya TP, Kushlinskii NE, Braga EA. Novel miRNA genes hypermethylated in breast cancer. Mol Biol (Mosk). 2016; 50:797-802. https://doi.org/10.7868/ s0026898416050104.

42. Ramalho-Carvalho J, Graca I, Gomez A, Oliveira J, Henrique R, Esteller M, Jeronimo C. Downregulation of miR-130b 301b cluster is mediated by aberrant promoter methylation and impairs cellular senescence in prostate cancer. J Hematol Oncol. 2017; 10:43. https://doi. org/10.1186/s13045-017-0415-1.

43. Yang C, Cai J, Wang Q, Tang H, Cao J, Wu L, Wang Z. Epigenetic silencing of miR-130b in ovarian cancer promotes the development of multidrug resistance by targeting colony-stimulating factor 1. Gynecol Oncol. 2012; 124:325-34. https://doi.org/10.1016/j.ygyno.2011.10.013.

44. Tahiliani M, Koh KP, Shen Y, Pastor WA, Bandukwala $\mathrm{H}$, Brudno Y, Agarwal S, Iyer LM, Liu DR, Aravind L, Rao A. Conversion of 5-methylcytosine to 5-hydroxymethylcytosine in mammalian DNA by MLL partner TET1. Science. 2009; 324:930-5. https://doi. org/10.1126/science. 1170116 .

45. Ito S, Shen L, Dai Q, Wu SC, Collins LB, Swenberg JA, He C, Zhang Y. Tet proteins can convert 5-methylcytosine to 5-formylcytosine and 5-carboxylcytosine. Science. 2011; 333:1300-3. https://doi.org/10.1126/science.1210597.

46. Okuzaki Y, Kaneoka H, Nishijima KI, Murakami S, Ozawa Y, Iijima S. Molecular cloning of chicken TET family genes and role of chicken TET1 in erythropoiesis. Biochem Biophys Res Commun. 2017; 490:753-9. https://doi. org/10.1016/j.bbrc.2017.06.113.

47. Dynan WS, Tjian R. The promoter-specific transcription factor Sp1 binds to upstream sequences in the SV40 early promoter. Cell. 1983; 35:79-87.

48. Black AR, Black JD, Azizkhan-Clifford J. Sp1 and kruppellike factor family of transcription factors in cell growth regulation and cancer. J Cell Physiol. 2001; 188:143-60. https://doi.org/10.1002/jcp.1111.

49. Olofsson BA, Kelly CM, Kim J, Hornsby SM, AzizkhanClifford J. Phosphorylation of Sp1 in response to DNA damage by ataxia telangiectasia-mutated kinase. Mol Cancer Res. 2007; 5:1319-30. https://doi.org/10.1158/15417786.mcr-07-0374.

50. Zhao G, Han C, Zhang Z, Wang L, Xu J. Increased expression of microRNA-31-5p inhibits cell proliferation, migration, and invasion via regulating $\mathrm{Sp} 1$ transcription factor in HepG2 hepatocellular carcinoma cell line. Biochem Biophys Res Commun. 2017; 490:371-7. https:// doi.org/10.1016/j.bbrc.2017.06.050.

51. Chiefari E, Brunetti A, Arturi F, Bidart JM, Russo D, Schlumberger M, Filetti S. Increased expression of AP2 and Sp1 transcription factors in human thyroid tumors: A role in NIS expression regulation? BMC Cancer. 2002; 2:35.

52. Wang L, Wei D, Huang S, Peng Z, Le X, Wu TT, Yao J, Ajani J, Xie K. Transcription factor Sp1 expression is a significant predictor of survival in human gastric cancer. Clin Cancer Res. 2003; 9:6371-80.

53. Jiang NY, Woda BA, Banner BF, Whalen GF, Dresser KA, Lu D. Sp1, a new biomarker that identifies a subset of aggressive pancreatic ductal adenocarcinoma. Cancer Epidemiol Biomarkers Prev. 2008; 17:1648-52. https://doi. org/10.1158/1055-9965.epi-07-2791.

54. Beishline K, Azizkhan-Clifford J. Sp1 and the 'hallmarks of cancer'. FEBS J. 2015; 282:224-58. https://doi.org/10.1111/ febs. 13148.

55. Siegfried Z, Eden S, Mendelsohn M, Feng X, Tsuberi BZ, Cedar H. DNA methylation represses transcription in vivo. Nat Genet. 1999; 22:203-6. https://doi.org/10.1038/9727.

56. Brandeis M, Frank D, Keshet I, Siegfried Z, Mendelsohn M, Nemes A, Temper V, Razin A, Cedar H. Sp1 elements protect a $\mathrm{CpG}$ island from de novo methylation. Nature. 1994; 371:435-8. https://doi.org/10.1038/371435a0. 
57. Macleod D, Charlton J, Mullins J, Bird AP. Sp1 sites in the mouse aprt gene promoter are required to prevent methylation of the CpG island. Genes Dev. 1994; 8:2282-92.

58. Clark SJ, Harrison J, Molloy PL. Sp1 binding is inhibited by $(\mathrm{m}) \mathrm{Cp}(\mathrm{m}) \mathrm{CpG}$ methylation. Gene. 1997; 195:67-71.

59. Strunnikova M, Schagdarsurengin U, Kehlen A, Garbe JC, Stampfer MR, Dammann R. Chromatin inactivation precedes de novo DNA methylation during the progressive epigenetic silencing of the RASSF1A promoter. Mol Cell Biol. 2005; 25:3923-33. https://doi.org/10.1128/ mcb.25.10.3923-3933.2005.

60. Fojas de Borja P, Collins NK, Du P, Azizkhan-Clifford J, Mudryj M. Cyclin A-CDK phosphorylates Sp1 and enhances Sp1-mediated transcription. EMBO J. 2001; 20:5737-47. https://doi.org/10.1093/emboj/20.20.5737.

61. Spengler ML, Guo LW, Brattain MG. Phosphorylation mediates $\mathrm{Sp} 1$ coupled activities of proteolytic processing, desumoylation and degradation. Cell Cycle. 2008; 7:62330. https://doi.org/10.4161/cc.7.5.5402.

62. Liu JL, Ye Y, Qian Z, Qian Y, Templeton DJ, Lee LF, Kung HJ. Functional interactions between herpesvirus oncoprotein MEQ and cell cycle regulator CDK2. J Virol. 1999; 73:4208-19.

63. Hanahan D, Weinberg RA. Hallmarks of cancer: The next generation. Cell. 2011; 144:646-74. https://doi. org/10.1016/j.cell.2011.02.013.

64. Burnside J, Ouyang M, Anderson A, Bernberg E, Lu C, Meyers BC, Green PJ, Markis M, Isaacs G, Huang E, Morgan RW. Deep sequencing of chicken microRNAs. BMC Genomics. 2008; 9:185. https://doi. org/10.1186/1471-2164-9-185.

65. Leone V, Langella C, D'Angelo D, Mussnich P, Wierinckx A, Terracciano L, Raverot G, Lachuer J, Rotondi S,
Jaffrain-Rea ML, Trouillas J, Fusco A. Mir-23b and miR-130b expression is downregulated in pituitary adenomas. Mol Cell Endocrinol. 2014; 390:1-7. https://doi. org/10.1016/j.mce.2014.03.002.

66. Zhao G, Zhang JG, Shi Y, Qin Q, Liu Y, Wang B, Tian K, Deng SC, Li X, Zhu S, Gong Q, Niu Y, Wang CY. MiR$130 \mathrm{~b}$ is a prognostic marker and inhibits cell proliferation and invasion in pancreatic cancer through targeting STAT3. PLoS One. 2013; 8:e73803. https://doi.org/10.1371/journal. pone.0073803.

67. Paudel D, Zhou W, Ouyang Y, Dong S, Huang Q, Giri R, Wang J, Tong X. MicroRNA-130b functions as a tumor suppressor by regulating RUNX3 in epithelial ovarian cancer. Gene. 2016; 586:48-55. https://doi.org/10.1016/j. gene.2016.04.001.

68. Stetler-Stevenson WG, Aznavoorian S, Liotta LA. Tumor cell interactions with the extracellular matrix during invasion and metastasis. Annu Rev Cell Biol. 1993; 9:54173. https://doi.org/10.1146/annurev.cb.09.110193.002545.

69. Luo Y, Liang F, Zhang ZY. PRL1 promotes cell migration and invasion by increasing MMP2 and MMP9 expression through Src and ERK1/2 pathways. Biochemistry. 2009; 48:1838-46. https://doi.org/10.1021/bi8020789.

70. Tabouret E, Boudouresque F, Farina P, Barrie M, Bequet C, Sanson M, Chinot O. MMP2 and MMP9 as candidate biomarkers to monitor bevacizumab therapy in highgrade glioma. Neuro Oncol. 2015; 17:1174-6. https://doi. org/10.1093/neuonc/nov094.

71. Sun J, Hemler ME. Regulation of MMP-1 and MMP-2 production through CD147/extracellular matrix metalloproteinase inducer interactions. Cancer Res. 2001; 61:2276-81. 